\title{
Synthesis, characterization and cytotoxicity appraisal of original 1, 2, 3-Triazole derivatives, against breast cancer cell lines (MDA-MB-231)
}

\author{
Mohammed Khalaf Mohammed *, Zainab Al-Shuhaib and Ali A. A. Al-Shawi \\ Department of Chemistry, College of Education for pure sciences, University of Basrah, 61004 Basrah, Iraq
}

\begin{abstract}
The present study established the efficient separate synthesis of four unique 1, 2, 3-triazole derivatives (M1, M2, M3, M4) via conducting 1,3-dipolar cycloaddition of $\mathrm{N}$-((4-azidophenyl) sulfonyl) acetamide, with substituted N-phenylmaleimide. FTIR, 1H NMR, 13C NMR, and mass spectra were utilized for the characterization of the triazoles. The cytotoxic activities of these compounds, with regards to breast cancer cell lines (MDA-MB-231), were then evaluated. The cytotoxicity pre-screening outcomes for $100 \mu \mathrm{M}$ portrayed a variety of actions, while the IC50 values with concentrations of $0-500 \mu \mathrm{M}$ for 48 hours, the results are 2.542 , 2.929, 2.429, and $2.864 \mu \mathrm{M}$ for the compounds M1, M2, M3, and M4 respectively. Remarkably, the M2 and M4 para-substituted compounds exhibited superior IC50 values, in comparison to the M1 and M3 ortho-substituted compounds. This suggests that the M1 and M3 compounds have the potential to perform as against breast cancer.
\end{abstract}

Keywords: Heterocyclic; 1,2,3-Triazole; 1, 3-dipolar cycloaddition; cytotoxicity; MTT assay; breast cancer.

\section{Introduction}

Triazole derivatives are most recommended compounds in the field of medicinal chemistry and drug discovery ${ }^{1,2}$. Several studies grasped the route of triazoles to reveal an innovative anti-inflammatory ${ }^{3}$, antifungal ${ }^{4}$, anticancer ${ }^{5}$, inhibitor ${ }^{6}$ and herbicidal ${ }^{7}$. The antioxidant and free radical scavenging activity of triazole derivatives are reported 8,9 , and there are indications that these derivatives can influence the development of breast cancer ${ }^{10,11}$. Kassem A. F. et al. designed a sequence of triazole glycosides that comes with appreciable anti-breast cancer activities (MCF-7) ${ }^{12}$. The synthesis of a series of triazoles by Gilandous M. et al. assisted in providing inhibition against the progress of VEGFR1 ${ }^{13}$. Rodarraju R. et al., utilized nucleoside derivatives to elaborate a triazole that comes with a cytotoxic impact on MCF-7 cells ${ }^{14}$. The purpose of the present work is to synthesize some 1,2,3-triazole derivatives in order to evaluate their action against MDA-MB231 breast cancer cells line Scheme 1 exhibits the chemical configuration of the synthesized compounds.

\section{Results and Discussion}

\subsection{Chemistry}

Cycloaddition reactions are commonly utilized to combine unsaturated molecules with the formation of heterocyclic compounds ${ }^{15}$. We applied 1,3-cycloaddition reaction for a three-stage synthesis of the compound derived from 1,2, 3-triazole. The initial stage requires prepare of substituted azide from N-((4-aminophenyl)sulfonyl)acetamide. The following stage involves the preparation of $\mathrm{N}$-phenyl maleimide derivatives. Then last stage, M1, M2, M3 and M4 compounds are synthesised through 1,3-dipolar cycloaddition reaction of $\mathrm{N}$-(4-Azido phenyl sulfonyl)acetamide with $\mathrm{N}$-phenyl maleimide derivatives. Scheme 1 shows the three stages of this synthesis process. FTIR, NMR and mass spectra were utilized for the characterization of the four compounds. 
1-<smiles>[R][Y]1cccc(N2C(=O)C=CC2=O)c1</smiles>

Step one , prepare N-maleimide derivatives

2-

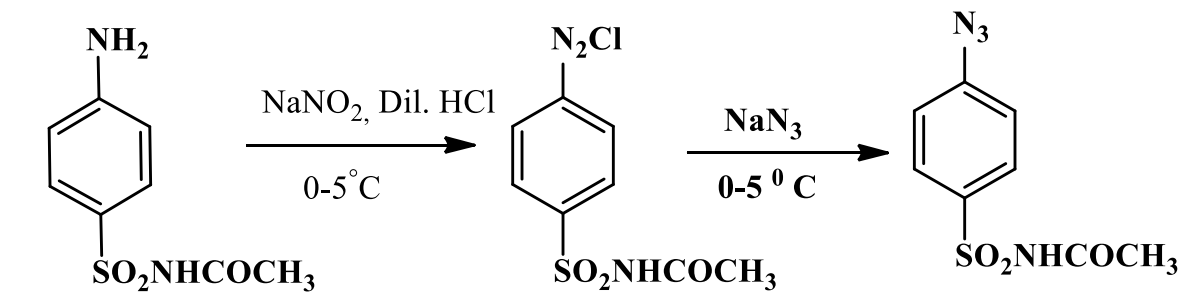

Step two, prepare N-(4-Azido phenyl sulfonyl) acetamide

3-<smiles>[R][X]c1cccc(N2C(=O)C=CC2=O)c1</smiles>

$\mathrm{R}=O-\mathrm{CH}_{3}, P-\mathrm{CH}_{3}, O-\mathrm{OCH}_{3}, P-\mathrm{CO}_{2} \mathrm{H}$<smiles>[R][X]C(C)OSc1ccc(N2N=NC3C(=O)N(c4ccccc4)C(=O)C32)cc1</smiles>

Step three, cycloaddition reaction between N-(4-Azido phenyl sulfonyl) acetamide and N-maleimide derivatives

\section{Scheme 1. exhibits the chemical configuration of the synthesized compounds}

\subsection{Cytotoxicity}

The efficiency of the synthesized triazole derivatives to frustration the expansion of MDA-MB231 human breast cancer cells was assessed via cell viability screening, following 48 hours of treatment with
$100 \mu \mathrm{M}$ for each compound, the M1, M2, M3 and M4 compounds exhibited average performances against cancer lines. We obtained the results, as shown in Table 1.

Table 1. Values of cell viability after $24 \mathrm{~h}$ of treatment with $100 \mu \mathrm{M}$ for each 1,2,3-triazole derivatives.

\begin{tabular}{|l|l|l|l|l|}
\hline Sample & Viability \% (1) & Viability \% (2) & Viability \% (3) & Average \% \\
\hline Control & 100 & 100 & 100 & $\mathbf{1 0 0}$ \\
\hline M1 & 62.432916 & 39.35743 & 42.0704846 & $\mathbf{4 7 . 9 5 3 6 1}$ \\
\hline M2 & 46.690519 & 59.036145 & 45.3744493 & $\mathbf{5 0 . 3 6 7 0 4}$ \\
\hline M3 & 73.881932 & 48.995984 & 44.0528634 & $\mathbf{5 5 . 6 4 3 5 9}$ \\
\hline M4 & 67.26297 & 48.594378 & 41.1894273 & $\mathbf{5 2 . 3 4 8 9 2}$ \\
\hline
\end{tabular}

\subsection{MTT assay}

GraphPad Prism 8.1 software was utilized to analyse the dose-response and computation IC50 values. The approximated IC50 values for the 1,2,3-triazole derivatives M1, M2, M3 and M4, were recorded as $2.541,2.929,2.429$ and $2.864 \mu \mathrm{M}$, respectively, as 
portrayed in Figure 1. The discrepancies in IC50 values could be attributed to the mode of the substituents, as well as their position ${ }^{16}$. As can be gathered from Figure 2, the M1 compound retains a methyl group in the para-position, the M2 compound retains a methyl group in the ortho-position, the M3 compound retains a methoxy group in the orthoposition, and the M4 compound retains a carboxylic group in the para-position. Our findings with regards to the activities of the investigated compounds indicate that: exceedingly active compounds are associated with IC50 < 1, fairly active compounds are associated with IC50 $<10$ and poorly active compounds are associated with IC50 $>10^{17,18}$. The IC50 values of the investigated compounds are represented in the order M3 $<\mathrm{M} 1<\mathrm{M} 4<\mathrm{M} 2$. The para-substituted compounds M1 and M3, displayed inferior IC50 values when compared to the orthosubstituted compounds M2 and M4. As depicted in Figure 1, the functional groups are namely the methoxy group (compound M3), the methyl group (compounds M1 and M2) and the carboxylic group (compound M4). These functional groups may have the capacity to influence the values of cytotoxicity and IC50. The more reduced IC50 value of the orthomethoxy group, in comparison to the other groups, may be attributed to (a) its tendency to initiate adverse steric activities, and (b) its pronounced lipophilicity and membrane partitioning inclinations ${ }^{19,20}$.
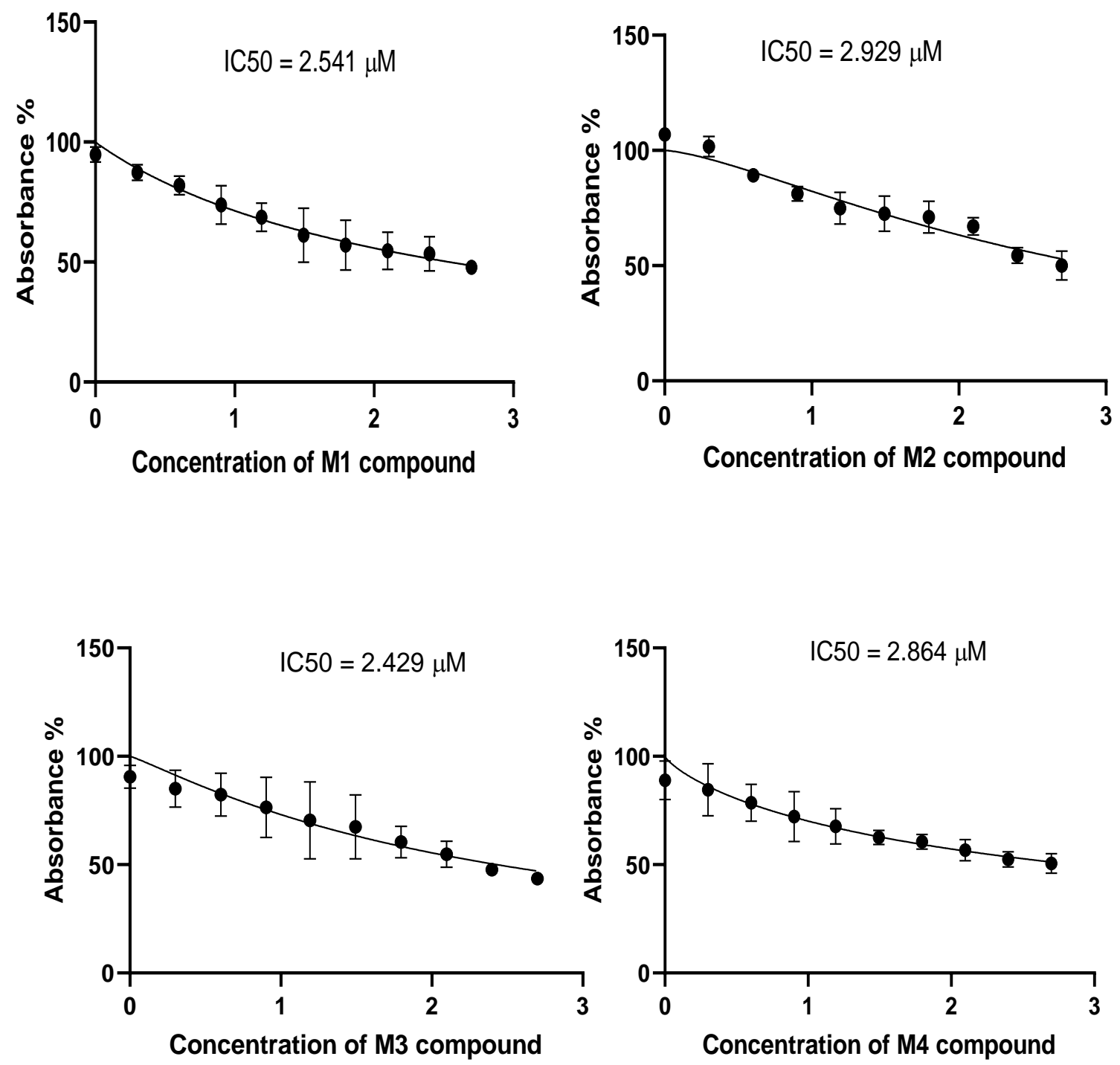

Figure 1. Show IC50 values of (M1, M2, M3, M4) compound for 48h against MDA-MB231 breast cancer cells

\section{Experimental Section}

\subsection{Chemistry}

The chemical materials and reagents required for this study were sourced from Aldrich sigma. Thin-layer chromatography was performed with the use of $0.20 \mathrm{~mm}$ thick silica plates. A Varian 500 was employed to identify $1 \mathrm{H}$ and $13 \mathrm{C}$ NMR, with the chemical shifts $(\delta)$ depicted in ppm utilizing TMS as a standard reference. The mass spectra were characterized on a JEOL JMS-5X 10217 in the EI genre. The molecular and parent ions $(\mathrm{m} / \mathrm{z})$ were stated. 
N-(4-Azido phenyl sulfonyl) acetamide synthesis ${ }^{21}$ Initially, a dropwise addition of a solution comprising 0.068 sodium nitrite $(0.1 \mathrm{mmol})$ in $5 \mathrm{~mL}$ water, to a stirred solution of $0.214 \mathrm{~g}$ sulfacetamide $(0.1 \mathrm{mmol})$, in $0.35 \mathrm{~mL}$ of concentrated hydrochloric acid, and $10 \mathrm{~mL}$ of water at $0^{\circ} \mathrm{C}$, was performed. This was followed, thirty minutes later, by the dropwise addition of a solution of $0.065 \mathrm{~g}$ sodium azide $(0.1 \mathrm{mmol})$ in $10 \mathrm{~mL}$ of water. During the cooling phase, $10 \mathrm{~mL}$ of water was gradually included in the mixture during 15 minutes of stirring. The precipitate, which was accumulated through suction filtration, was subsequently re-crystallized from ethanol to produce white needle crystals. As illustrated in Figure 1, the yield is $98 \%$, while the m.p. was $142-143^{\circ} \mathrm{C}$.
N-Arylmaleimides synthesis process ${ }^{22-24}$

(20 mmol) of maleic anhydride and $25 \mathrm{~mL}$ of diethyl ether were introduced into a $100 \mathrm{~mL}$ two-neck flask. This flask was equipped with a magnetic stirrer bar, a reflux condenser, and a dropping funnel. 1 equivalent $(20 \mathrm{mmol})$ of the aniline derivatives in $5 \mathrm{~mL}$ of diethyl ether was added to the solution of maleic anhydride. The consequential dense suspension was subjected to stirring at room temperature for an hour. The N-substituted maleamic acid was filtered, dried, and delivered to a flask comprising a solution of anhydrous sodium acetate $(8 \mathrm{mmol})$ in acetic anhydride $(6.7 \mathrm{~mL})$. The mixture was then stirred for $30 \mathrm{~min}$ over a steam bath. The mixture left to cool at room temperature, and later it was transferred into $100 \mathrm{~mL}$ of iced water. The resulting precipitate was filtered, washed thrice with $30 \mathrm{~mL}$ of cold water. Eventually, the products were acquired through the recrystallization of the crude $\mathrm{N}$-substituted maleimide from ethanol/water.

Table 2. Physical properties of some maleimide derivatives preparatory.

\begin{tabular}{|c|c|c|c|c|}
\hline & Name & mp ${ }^{\circ} \mathbf{C}$ & color & Yield\% \\
\hline MPM1 & N-(2-Methylphenyl)maleimide & $47-48$ & Beige crystalline solid & 77 \\
\hline MPM2 & N-(4-Methylphenyl)maleimide & $158-160$ & Yellow powder & 84 \\
\hline MPM3 & N-(2-Methoxyphenyl)maleimide & $109-111$ & Brown crystalline solid.Yield & 70 \\
\hline MBA & 4-maleimidobenzoic acid & $232-234$ & White crystalline & 85 \\
\hline
\end{tabular}

Synthesis of 1, 2, 3-triazoles derivatives (M1-4) A general description of the process

$\mathrm{N}$-substituted maleimide (1 mmol) was combined with N-((4-azidophenyl) sulfonyl) acetamide (1mmol) before the mixture was subjected to heating for 6 and 15 hours. The resulting precipitate was then filtered and purified through re-crystallization in chloroform and hexane.

\section{N-((4-(4,6-dioxo-5-(o-tolyl)-4,5,6,6a- tetrahydropyrrolo[3,4-d][1,2,3]triazol-1(3aH)- yl)phenyl)sulfonyl)acetamide. M1}

White solid; yield $62 \%, \mathrm{R}_{f} \quad 0.70$, m.p. $153-155^{\circ} \mathrm{C}$. ${ }^{1} \mathrm{H}-\mathrm{NMR}$ (DMSO, $\left.500 \mathrm{MHz}\right) \delta$ : $1.91(1 \mathrm{(s)}, 3 \mathrm{H})$, $2.33(2(\mathrm{~s}), 3 \mathrm{H}), 5.36\left(3, \mathrm{~d}, J_{3,4}=10,1 \mathrm{H}\right), 6.02$ $\left(4, \quad \mathrm{~d}, \quad J_{4,3}=10,1 \mathrm{H}\right), 7.30-6.02(5,6,7,8, \quad(\mathrm{~m})$, 4Haromatic), $7.79\left(9, \mathrm{~d}, J_{9,10}=10,2 \mathrm{H}\right), 7.96(10, \mathrm{~d}$, $\left.J_{10,9}=10, \quad 2 \mathrm{H}\right), 12.04(11, \mathrm{~s}, \mathrm{H})$.

${ }^{13}$ C-NMR (DMSO, $\left.125 \mathrm{MHz}\right) \delta: 21.91\left(1, \mathrm{CH}_{3}\right)$, $23.66\left(2, \mathrm{CH}_{3}\right), 56.85(3, \mathrm{CH}), 84.63(4, \mathrm{CH})$, $100.82(5, \mathrm{CH}), 104.40(6, \mathrm{CH}), 113.63(7, \mathrm{C})$, $129.60(8,2 \times C H), 124.43(9, \mathrm{CH}), 127.21 \quad(10$, $\mathrm{CH}), 133.65$ (11, C), 139.00 (12, C), 143.73 (13, C), $169.16(14, \mathrm{CO}), 169.69$ (15, CO), $171.42(16, \mathrm{CO})$ MS [EI+] m/z (\%):427 [M]+, $399\left[\mathrm{C}_{19} \mathrm{H}_{17} \mathrm{~N}_{3} \mathrm{O}_{6} \mathrm{~S}\right]$, $188\left[\mathrm{C}_{10} \mathrm{H}_{8} \mathrm{~N}_{2} \mathrm{O}_{2}\right] \cdot(100), \quad 83 \quad\left[\mathrm{C}_{4} \mathrm{H}_{5} \mathrm{NO}\right]^{+}, \quad 69$ $\left[\mathrm{C}_{4} \mathrm{H}_{7} \mathrm{~N}\right]^{+}, 57\left[\mathrm{C}_{3} \mathrm{H}_{7} \mathrm{~N}\right]^{+}, 43\left[\mathrm{C}_{2} \mathrm{H}_{5} \mathrm{~N}\right]^{+}$, as shown in Figures 2, 6 and 10.

N-((4-(4,6-dioxo-5-(p-tolyl)-4,5,6,6atetrahydropyrrolo[3,4-d][1,2,3]triazol-1(3aH)yl)phenyl)sulfonyl) acetamide. M2 White solid $50 \%, \mathrm{R}_{f} 0.66$, m.p. $179-180^{\circ} \mathrm{C}$.
${ }^{1} \mathrm{H}-\mathrm{NMR}$ (DMSO, $\left.500 \mathrm{MHz}\right) \delta: 1.92$ (1 (s), 3H), $2.34\left(2\right.$ (s), 3H), 5.37 (3 (d), $\left.J_{3,4}=10,1 \mathrm{H}\right), 6.02$ (4 (d), $\left.J_{4,3}=10,1 \mathrm{H}\right), 7.165\left(5(\mathrm{~d}), J_{5,8}=5,2 \mathrm{H}\right)$, $7.29\left(6(\mathrm{~d}), J_{6,7}=10,2 \mathrm{H}\right), 7.79\left(7\right.$ (d), $J_{7,6}=10$, $2 \mathrm{H}), 7.965\left(8(\mathrm{~d}), J_{8,5}=5,2 \mathrm{H}\right), 12.04(9(\mathrm{~s}), 1 \mathrm{H})$.

${ }^{13} \mathrm{C}-\mathrm{NMR}$ (DMSO, $\left.125 \mathrm{MHz}\right) \delta$ : 16.76 (1, CH3), 23.68 (2, CH3), $57.37(3, \mathrm{CH}), 85.03(4, \mathrm{CH})$, $115.57(5,6,2 \mathrm{xCH}), 128.39$ (9, C), $129.95(7,8$, $2 \times \mathrm{CH}), 131.22(10, \mathrm{C}), 134.01(11, \mathrm{C}), 135.49$ (12, C), $169.22(13, \quad \mathrm{CO}), 169.47$ (14, CO), $171.36(15, \mathrm{CO})$.

MS m/z (\%): $427[\mathrm{M}]+, 399\left[\mathrm{C}_{19} \mathrm{H}_{17} \mathrm{~N}_{3} \mathrm{O}_{5} \mathrm{~S}\right]$ (100), $276\left[\mathrm{C}_{17} \mathrm{H}_{14} \mathrm{~N}_{2} \mathrm{O}_{2}\right]^{+}, \quad 223 \quad\left[\mathrm{C}_{14} \mathrm{H}_{12} \mathrm{~N}_{2} \mathrm{O}\right]^{+}$, $43\left[\mathrm{C}_{2} \mathrm{H}_{5} \mathrm{~N}\right] \cdot(100)$, as shown in Figures 3, 7, and 11 .

\section{N-((4-(5-(2-methoxyphenyl)-4,6-dioxo-4,5,6,6a-} tetrahydropyrrolo[3,4-d] [1,2,3]triazol-1(3aH)yl)phenyl) sulfonyl) acetamide. M3

White solid, yield $73 \%$; $\mathrm{R}_{f} 0.55$; m.p. $164-165^{\circ} \mathrm{C}$. ${ }^{1} \mathrm{H}-\mathrm{NMR}$ (DMSO, $\left.500 \mathrm{MHz}\right) \delta: 1.91(1, \mathrm{~s}, 3 \mathrm{H})$, $3.595(2, \mathrm{~s}, 3 \mathrm{H}), 5.38\left(3, \mathrm{~d}, J_{3,4}=10,1 \mathrm{H}\right), 6.03$ $\left(4, \quad \mathrm{~d}, J_{4,3}=10, \mathrm{H}\right), 7.43-7.48(5,6,7,8, \quad \mathrm{~m}$, 4Haromatic), $7.79\left(9, \mathrm{~d}, J_{9,10}=5,2 \mathrm{H}\right), 7.96(10, \mathrm{~d}$, $\left.J_{10,9}=5,2 \mathrm{H}\right), 12.04(11, \mathrm{~s}, \mathrm{H}) .{ }^{13} \mathrm{C}-\mathrm{NMR}$ (DMSO, $125 \mathrm{MHz}) \delta: 23.67$ (1, CH3), 56.48 (2, OCH3), $57.15(3, \quad \mathrm{CH}), 84.87(4, \mathrm{CH}), 112.92(5, \mathrm{CH})$, $115.48(6,2 * \mathrm{CH}), 121.12(7, \mathrm{C}), 130.01$

$(8, \quad 2 * \mathrm{CH}), 129.43(9, \quad \mathrm{CH}), 131.53(10, \mathrm{CH})$, 133.86 (11, C), 143.64 (12, C), 154.80 (13, C), $169.10(14,16,2 * \mathrm{CO}), 154.3(15, \mathrm{CO}), 168.7$ (16, CO), 170.7 (17, CO). MS m/z (\%): $443[\mathrm{M}]+$, $415\left[\mathrm{C}_{19} \mathrm{H}_{17} \mathrm{~N}_{3} \mathrm{O}_{6} \mathrm{~S}\right]^{+}, 384\left[\mathrm{C}_{18} \mathrm{H}_{15} \mathrm{~N}_{3} \mathrm{O}_{5} \mathrm{~S}\right]$, 
$69\left[\mathrm{C}_{4} \mathrm{H}_{7} \mathrm{~N}\right]^{+}, 57[? ?], 43\left[\mathrm{C}_{2} \mathrm{H}_{5} \mathrm{~N}\right]^{+}(100)$, as shown in Figures 4, 8 and 12.

4-(1-(4-(N-acetylsulfamoyl)phenyl)-4,6-dioxo3a,4,6,6a-tetrahydropyrrolo $[3,4-d][1,2,3]$ triazol$5(1 \mathrm{H})$-yl) benzoic acid. M4

White solid, yield $80 \%$; Rf 0.46; m.p. $173-175^{\circ} \mathrm{C}$. ${ }^{1} \mathrm{H}-\mathrm{NMR}$ (DMSO, $\left.500 \mathrm{MHz}\right) \delta: 1.91(1, \quad \mathrm{~s}, 3 \mathrm{H})$, $5.40\left(2, \mathrm{~d}, J_{2,3}=10,1 \mathrm{H}\right), 6.05\left(3, \mathrm{~d}, J_{3,2}=10\right.$, $1 \mathrm{H}), 7.46\left(4, \mathrm{~d}, J_{4,5}=5,2 \mathrm{H}\right), 7.97\left(5, \mathrm{~d}, J_{5,4}=5\right.$, $2 \mathrm{H}), 8.04\left(6, \mathrm{~d}, J_{6,7}=5,2 \mathrm{H}\right), 8.06\left(7, \mathrm{~d},, J_{7,6}=5\right.$, 2H), $12.00 \quad(8, \quad \mathrm{~s}, \quad \mathrm{NH}) .{ }^{13} \mathrm{C}-\mathrm{NMR}$ (DMSO, 125

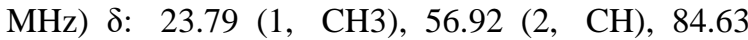
$(3, \mathrm{CH}), 115.41(4,2 \mathrm{xCH}), 127.56(5,2 \times \mathrm{CH})$, $131.49(6, \mathrm{C}), 129.89(7,2 \times \mathrm{xH}), 130.40(8,2 \mathrm{CH})$, 133.96 (9, C), 135.69 (10, C) 143.58 (11, C), $165.54(12, \mathrm{CO}), 166.99\left(13, \mathrm{CO}_{2} \mathrm{H}\right), 169.37(14$, CO), 171.03 (15, CO). MS m/z (\%): $457[\mathrm{M}]+$ (),429 $\left[\mathrm{C}_{19} \mathrm{H}_{15} \mathrm{~N}_{3} \mathrm{O}_{7} \mathrm{~S}\right]^{+}, \quad 217\left[\mathrm{C}_{11} \mathrm{H}_{7} \mathrm{NO}_{4}\right]^{+}, 137$ $[\mathrm{C} 7 \mathrm{H} 7 \mathrm{NO} 2]^{+}, 109\left[\mathrm{C}_{5} \mathrm{H}_{3} \mathrm{NO}_{2}\right]^{+}(100), 69\left[\mathrm{C}_{4} \mathrm{H}_{7} \mathrm{~N}\right]^{+}$, $43\left[\mathrm{C}_{2} \mathrm{H}_{5} \mathrm{~N}\right]^{+}$, as shown in Figures 5, 9 and 13.

\subsection{Anti-breast cancer activity of 1, 2, 3-triazoles derivatives \\ Cell culture}

Human breast cancer MDA-MB231 cells were growth in a $10 \mathrm{~cm}$ plate, holding DMEM fortified with $10 \%$ FBS, 100 units $/ \mathrm{mL}$ of penicillin and $100 \mu \mathrm{g} / \mathrm{mL}$ of streptomycin. The temperature was maintained at $37^{\circ} \mathrm{C}$, while $5 \%$ of $\mathrm{CO} 2$ was applied to humidify the atmosphere 25,27 .

\subsection{Cytotoxicity}

The 24-hour development of MDA-MB231 cells, in 96 wells/plates, was followed by their treatment with $100 \mu \mathrm{M}$ of each triazole compound (M1, M2, M3, M4) for a 48-hour. A microplate reader was used to measure the cell viability at $570 \mathrm{~nm}$, this testing procedure was repeated in three wells ${ }^{26}$.

\subsection{MTT assay}

The 48-hour development of MDA-MB231 cells, in 96 wells/ plates, was followed by their treatment with (0-500) $\mu \mathrm{M}$ of each compound (M1, M2, M3, M4) for a 48-hour period. was used to measure the cell viability at $570 \mathrm{~nm}$, this testing procedure was repeated in three wells ${ }^{25,27}$.

\subsection{Statics analysis}

The GraphPad Prism 8.1 was used to estimate IC50 value. $\mathrm{P}<0.0001$ were deemed statistically significant. The experiments were repeated in 3 wells

\section{Conclusions}

The 1,2,3-triazole is a convincing chemical design for the generation of innovative anti-cancer mediators. The methoxy group has the potential to play a significant cancer prevention role, while 1,2 , 3- triazole compounds, substituted with methoxy groups, can pave the way towards the development of innovative anti-cancer treatment agents.

\section{Acknowledgements}

The research was own funded by authors. We are sincerely grateful to Dr Azhar Rasul, Assistant Professor, Cell and Molecular Biology Lab, Department of Zoology and Cytology, Government College University, Faisalabad 38000, Pakistan, for his wholehearted support and assistance during this anti-cancer investigation.

6. Conflicts of interest: The authors declare there is no conflict of interest.

\section{References}

1- F. A. Almashal and M. Khalaf,1,3-Dipolar Cycloaddition for 4-Azidobenzene Sulfonamide with Acetylenic and Olefinic Compounds, Basrah Journal of Science, 2014 .32(1), 49-69.

2- K. Rajeev, C. S. Prabodh, S.Y. Mohammed, Pharmacological significance of triazole scaffold, Journal of Enzyme Inhibition and Medicinal Chemistry, 2011, 26(1), 1-21.

3- T. W. Kim, Y. Yong, S.Y. Shin, H. Jung, K. H, Park,Y. H. Lee,Y. Lim, K. Y. Jung, Synthesis and biological evaluation of phenyl-1H-1,2,3triazole derivatives as anti-inflammatory agents. Bioorg Chem. 2015, 59,1-11.

4- Q. Li, W. Tan, C. Zhang, G. Gu, Z Guo, Synthesis of water soluble chitosan derivatives with halogeno-1,2,3triazole and their antifungal activity." Int J Biol Macromol, 2016, 91, 623-9.

5- J. A. dos Santos, R. C. N. Reis Corrales, F. R. Pavan, "Synthesis and antitubercular evaluation of new 1,2,3-triazole derivatives of carbohydrates", Mediterr.J.Chem., 2012,1(6), 282-288.

6- J. C. Li, J. Zhang, M. C. Rodrigues, D. J. Ding, J. P. Longo, R. B. Azevedo, L. A. Muehlmann, C. S. Jiang, Synthesis and evaluation of novel 1,2,3-triazole-based acetylcholinesterase inhibitors with neuroprotective activity. Bioorg Med Chem Lett. 2016, 26(16), 3881-5.

7- X.S. Pan, N.B. Sun, C. Lei, F.Y. He, Crystal Structure, DFT Calculations and Herbicidal Activity of A New 1,2,3-Triazole Derivative Containing Sulfonyl Group, J. Chem. Soc. Pak., 2014, Vol. 36, No. 2.

8- W. Tan, Q. Li, W. Li, F. Dong, Z. Guo, Synthesis and antioxidant property of novel 1,2,3-triazolelinked starch derivatives via 'click chemistry'. Int. J. Biol. Macromol., 2016, 82, 404-10.

9- Q. Li, X. Sun, G. Gu, Z. Guo, Novel Water Soluble Chitosan Derivatives with 1,2,3Triazolium and Their Free Radical-Scavenging Activity. Mar Drugs. 2018, 16(4), pii: E107.

10-D. Dheer, V. S. Shankar, Medicinal attributes of 1,2,3-triazoles: Current developments, Bioorganic Chemistry, 2017, 71, 30-54. 
11-A. Salam, F. Hassan, K. Anil, A. Abdul Hameed, E. Yousif, Chemotherapy of breast cancer by heterocyclic compounds, Int. J. Pharm. Sci. Rev. Res., 41(2), 2016, Article No. 42, 225-231.

12-A. F. Kassem, E. Abbas, D. S. El-Kady, H. M. Awad, W. A. El-Sayed, Design, Synthesis and Anticancer Activity of New Thiazole-Tetrazole or Triazole Hybrid Glycosides Targeting CDK2 via Structure-Based Virtual Screening. Mini Rev. Med. Chem., 2018, doi: 10.2174/ 1389557519666181231121217.

13-M. Gilandoust, K. B. Harsha, C. D. Mohan, A. R. Raquib, S. Rangappa, V. Pandey, P. E. Lobie, K. S. Basappa, Synthesis, characterization and cytotoxicity studies of 1,2,3-triazoles and 1,2,4triazolo [1,5-a] pyrimidines in human breast cancer cells, Bioorg Med Chem Lett. , 2018, 28(13), 2314-2319. doi: 10.1016/j.bmcl.2018.05.020.

14-R. R. Ruddarraju, A. C. Murugulla, R. Kotla, C. Babu Tirumalasetty, R. Wudayagiri, S. Donthabakthuni, R. Maroju, K. Baburao, L. S. Parasa, Design, synthesis, anticancer, antimicrobial activities and molecular docking studies of theophylline containing acetylenes and theophylline containing 1,2,3-triazoles with variant nucleoside derivatives, Eur. J. Med. Chem., 123, 379-396. doi: 10.1016/ j.ejmech, 2016,07.024.

15-C.O. Kappe and E. V. D. Eycken, Click chemistry under non-classical reaction conditions, Chem. Soc. Rev., 2010, 39, 1280-1290.

16-P. Veda, P. Ratchanok, A. Nuttapat, W. Apilak, N. Chanin, P. Supaluk, R. Somsak, P. Virapong, Discovery of novel 1,2,3-triazole derivatives as anticancer agents using QSAR and in silico structural modification, Springer Plus, 2015, 4, 571.

17-E. Virapong, R. G. Díaz-Peñate, A. EstévezBraun, A. G. Ravelo, J. M. García-Castellano, L. Pardo, M. Campillo, Synthesis and pharmacophore modeling of naphthoquinone derivatives with cytotoxic activity in human promyelocytic leukemia HL-60 cell line, J. Med. Chem., 2007, 50, 696-706.

18-V. Prachayasittikul, R. Pingaew,

A. Worachartcheewan, C. Nantasenamat, S. Prachayasittikul, S. Ruchirawat, V. Prachayasittikul, Synthesis, anticancer activity and QSAR study of 1,4-naphthoquinone derivatives, Eur. J. Med. Chem., 2014, 84, 247-263. doi:10.1016/j.ejmech. 2014, 07, 024.

19-M. Alessandro, B. Olga, R. Daniele, B. Tatiana, S. Gianni, T. Massimo and De .R. Carmela, Research Progress in the Modification of Quercetin Leading to Anticancer Agents, Molecules, 2017, 22, 1270.

20-L. Wang, J. Wang, L. Fang, Z. Zheng, D. Zhi, L. Shim, C.Ho, H. Zhao, Anticancer Activities of Citrus Peel Polymethoxyflavones Related to Angiogenesis and Others" Biomed Res Int. 2014, ID 453972.

21-F. Al-mashal and N. Hameed, Uncatalyzed thermal synthesis of new 1,2,3-triazole Derivaties, Journal of Basrah Reseaches, 2014, $40,1$.

22-A. Abdolmaleki, P. Pashaie, Synthesis and Characterization of Polyamide Containing Maleimide Pendant Group, Journal of Applied Chemical Research, 2015, 9, 3, 43-54.

23-R. Moreno-Fuquen, C. T. Juan, E. Javier, 4-(2,5-Dioxo-2,5-dihydro-1H-pyrrol-1yl)benzoic acid: X-ray and DFT-calculated structure Acta Cryst., 2011, C67, 67-70.

24-N. Matuszak, G. Giulio, M. G. Labar and D. M. LamberSt, Synthesis and in Vitro Evaluation of $\mathrm{N}$-Substituted Maleimide Derivatives as Selective Monoglyceride Lipase Inhibitors, J. Med. Chem., 2009, 52, 7410-7420.

25-V. Krishnan, R. Kalyanaraman, G. Fathima, K. Sheriff, M. Illiyas, H. Ahmad Rather, R. Thangam and T. Krishnan, "green biosynthesis of silver nanoparticles from elettaria cardamomum (seed) and it's in vitro cytotoxic activity", 2015, V4, 723-733.

26-A. A. Al Shawi, R. M. Khan, F. Iqbal, M. T. Eupatilin, "A flavonoid compound isolated from the artemisia plant, induces apoptosis and G2/M phase cell cycle arrest in hu' ${ }^{\mathrm{i}}$ man melanoma A375 cells. African Journal of Pharmacy and Pharmacology, 2011, 5, 582-588.

27-V. Krishnan, R. Kalyanaraman, "invitro toxicity of silver nanoparticles synthesized by using cloves of syzygium aromaticum against hep-2 cells derived from larynx carcinoma", Int. J. Pharm. Bio. Sci., 2016, 7, 442-447. 